\title{
Bolus Dosing Unit
}

National Cancer Institute

\section{Source}

National Cancer Institute. Bolus Dosing Unit. NCI Thesaurus. Code C48476.

A dosing unit equal to the amount of active ing redient(s) contained in a bolus. 